\title{
Medical and Islamic Perspectives on Human Immunodeficiency Virus Infection and its Prevention
}

\author{
Abdullah $F^{a}$, Hashi $A A^{b}$, Said $A H^{a}$, Mat Nor $M B^{c}$ \\ ${ }^{a}$ Department of Family Medicine, Kulliyyah of Medicine, International Islamic University Malaysia, 25200 \\ Kuantan, Pahang. \\ bepartment of Biotechnology, Kulliyyah of Science, International Islamic University Malaysia, 25200 \\ Kuantan, Pahang \\ ${ }^{\circ}$ Department of Anesthesiology and Critical Care, Kulliyyah of Medicine, International Islamic University \\ Malaysia, 25200, Kuantan, Pahang
}

\section{INTRODUCTION}

Human Immunodeficiency Virus (HIV) that causes Acquired Immune Deficiency Syndrome (AIDS) is one of the world's most serious health and nation-state destructions. It creates long-term economic and psychosocial impact on the lives of individuals, families and communities. Since the first reported case of HIV/AIDS in Malaysia in 1986, its prevalence has escalated significantly. As of December 2017, there are over 115,263 reported cases of HIV infections in the country and over 40,000 people died from HIV/AIDS. ${ }^{1}$ Although many religious people regarded HIV infection as a divine punishment for their sins of sexual promiscuity, Islamic teaching emphasises the prevention of the disease and care for people living with HIV or AIDS. It is imperative to discuss the Islamic perspectives in providing ways to prevent the spread of HIV and support to people living with HIV (PLHIV). This article focuses on epidemiological data; highlight the burden of HIV infection/AIDS in Malaysia and its impact on the society, HIV infection from medical perspective and its preventive measures from Islamic viewpoints. A good teamwork among healthcare providers and religious leaders is compulsory as it may improve the preventive strategies to curb the disease in the country.

\section{DEMOGRAPHIC BACKGROUND}

Since beginning of the epidemic, HIV burden relies heavily on government financial resource as in 2017, the total expenditure for HIV response was RM144 million and more than $95 \%$ was funded by domestic public source. ${ }^{1,2}$ Six states in Peninsula Malaysia; Johor (15.6\%), Selangor (15.7\%), Kelantan (10.3\%), Pahang (9.6\%) and Terengganu (8.4\%) and WPKL (8.7\%) account for more than two thirds of all PLHIV in Malaysia. ${ }^{1,2}$ Generally, PLHIV is predominant among males (89\%) but over time, the percentage of new cases HIV positive in women is increasing from 9.5\% in 2000 to $13.6 \%$ in $2017 .{ }^{1}$ Data in 2017 showed a total reported HIV infection in Malaysia as 115,263 (1986-2017), with total reported HIV among people who are injecting drug (PWID) and sexually transmitted HIV as 68,507 and 36,237 respectively. ${ }^{1,2}$ The pattern has shifted from PWID to sexual transmission with $\mathrm{PWID} /$ sexual transmission ratio reversing significantly from 3:1 to $1: 18$ in 2017. ${ }^{1,2}$ Out of 3,347 new HIV infections, $77 \%$ were between the aged of 20-39 years, 457 were female and 22 new cases of children aged less than 13 years old. ${ }^{1,2}$ Majority of new infection were from homosexual/ bisexual (51\%) and heterosexual (40\%) transmission whilst vertical transmission (mother-to-child) was $1 \%$ and among PWID was 3\%. ${ }^{1,2}$ The increasing rate of sexual transmission and HIV infection in women is alarming as it could increase mother-to-child transmission as the consequence if primary intervention is not effective. Table-1 shows regional and Malaysian HIV statistic as in 2017.

\section{MEDICAL PERSPECTIVE}

\section{HIV Infection}

HIV is a retrovirus that has several targets including dendritic cells, macrophages and CD4+ T cells which are important for body immune defense. HIV-1 generally enters the host through ano-genital mucosa and then disseminates to organs once it enters the blood. It reproduces and kills the cells. Eventually the body loses its ability to fight the HIV and is now unable to form protection from any kind of infection thus progresses to AIDS if untreated. Acute HIV infection can mimic other viral infections and can be difficult to diagnose unless it involves key population groups who are at increased risk of HIV. Key population group is defined as vulnerable and most-at 
-risk population which includes PWID, female sex workers (FSW), transgender people (TG) and men who have sex with men (MSM). They represent the most severely affected population with infection rates exceeding $5 \%$ and a large proportion of them are above 25 years old. ${ }^{3}$ In Malaysia, HIV serology test is used as a screening test to key population group and this test is also used in pre-marital and antenatal screening.

\section{Treatment as Prevention}

Basic principles of healing are to maintain good health, treatment of arising diseases and prevention. The act of healing is already Islamic and with guidance, Al-Qur'an offers the complete healing for all mental, spiritual and physical diseases as recited in surah al-Isra' 17:82 "And We send down of the Qur'an that which is healing and merciful for the believers, but it does not increase the wrongdoers except in loss". ${ }^{4}$ Significantly treating HIV infection is an important concern in Islamic perspective relating to maintaining good health and to curb the disease transmission. Antiretroviral therapy (ART) plays a pivotal role in preventing transmission and to help infected people to stay healthy. Antiviral drugs suppress the viral load to undetectable level and increase the CD4 count to improve immune competency and are thus essential to be taken lifelong. In Malaysia as of 2017, only 54\% of adults and children living with HIV have access to ART which was lower than the estimated target of $79 \%{ }^{3}$

Although Malaysia has made a significant progress since 1990 in expanding the availability and accessibility of the treatment and prevention, more efforts need to be engaged on psychosocial issues especially related to welfare, care and support in order to increase the number of PLHIV receiving treatment and to enhancelong-term follow-up. The latest Malaysian Consensus Guidelines on ART (2017) recommends that startingART to all adults ( $>18$ years old) with HIV regardless of the CD4 count. ${ }^{5}$ The consensus indicates that all known PLHIV should receive ART no matter how psychosocially impoverished or geographically isolated they may be. Studies revealed that ART improves survival and delays progression of the disease. A few studies supported the initiation of ART regardless of CD4 count. ${ }^{6,7}$ Prophet Mohammad (Sallallaahu Alaihi Wasallam) said, "Allah has sent down diseases and for every disease there is a cure. So take your medicine but do not use anything haram (unlawful) as medicine." [Narrated by Abu l-Darda (Radiallahu anha). Sunan Abu Dawud]. The hadith above point that more out-reach programme should be organized by medical and Islamic workforces to work hand in hand with local communities to educate and cultivate awareness of HIV infection so that people can come forward to test for HIV and subsequently if needful, to take early treatment to suppress the viral load as this would substantially contribute to HIV prevention.

\section{Eliminating Mother-To-Child Transmission as Prevention}

Mother-to-child risk of infection is $5 \%-15 \%$ during pregnancy, $20 \%$ during delivery and 33\% during breast feeding. Without any intervention, between $30 \%-45 \%$ of children born to HIV positive mothers will become infected ${ }^{8,9}$ The risk of mother-to-child transmission can be reduced to less than $2 \%$ by prescribing ART during pregnancy, recommending caesarian section and avoiding breast feeding. Integrated strategies for eliminating mother-to-child transmission (MTCT) in Malaysia include premarital and antenatal screening of HIV, treatment policy for pregnant mothers, prevention of transmission through delivery and breastfeeding, treatment prophylaxis for infants delivered by PLHIV mother and HIV care for mother and child as shown in Figure -1. Some mother will feel demoralized for not breastfeeding their children. However, prevention of transmission through breast milk is necessary to ensure the child be free from the disease. The religious laws regarding breastfeeding may give parents a degree of flexibility as He says in the Quran al-Nisa' 4:43 "And if you are ill, or on a journey, or one of you comes after answering the call of nature, or you have been in contact with women (by sexual relations) and you find no water, perform Tayammum with clean earth and rub therewith your faces and hands (Tayammum)" "The recitation points toward that occasionally to maintain health, the 'sick' person is prevented from using water lest it harms him and alternative method is advisable.

Nonetheless, prevention of mother-to-child transmission (PMTCT) should start from adolescent period where engagement to premarital sex may have possibly occurred. The prevalence of adolescent aged 12-17 years old in Malaysia 


Eliminating Mother-To-Child Transmission

Premarital Screening

Early HIV detection and treatment before conception Treatment policy for pregnant mother - Option B+ using

Antenatal Screening HAART and continue for life

Prevention of Transmission Through Breast Milk

Total substitution of breast feeding with infant formula given free extended to 24 months

HIV DNA PCR at 14-21 days, 1-2 months and 4-6 months HIV antibody at 12-18 months

Early Infant Diagnosis

Treatment policy for infant Syrup AXT for 6 weeks / or Single dose NVP at birth and AZT for 6 weeks

HIV care extended from tertiary to primary care level

HIV Care at all government health clinics.

Figure 1: Eliminating MTCT Program in Malaysia from 2015 onward

reported with ever-had sex was $8.3 \%{ }^{10}$ Although the prevalence of premarital sex among schoolgoing adolescents in Malaysia is relatively low, it could still give a great impact to the increment of HIV sexual transmission.

Figure-2 shows integrated strategies for PMTCT. Primary prevention should start early during adolescent period when the girls are already in childbearing age and more exposed to peer influence and curiosity. Harm reduction programme in Malaysia refers to methadone maintenance therapy (MMT) and needle syringe exchange programme (NSEP) which aims at preventing HIV infection by reducing sharing of contaminated needles, and was introduced in 2006. ${ }^{11}$ Additionally, free condoms are also made available in certain NGO and government outlets to prevent unprotected sex. Harm reduction programme has revealed a significant reduction of notification rate of new cases from $21.88 \%$ in 2006 to 16.74 in 2007 and continuously decreasing to $10.3 \%$ in $2017 .{ }^{11}$ These programme have also been shown to be costeffective as well as averting approximately 12,000 new HIV infections. For future expansion, increased awareness and understanding of the concept of harm reduction from the Islamic perspective should be attempted. ${ }^{12}$ Harm reduction programme should be integrated with awareness, counselling, spiritual and religious inputs by various agencies working as a team. When viewed through the Islamic principles of the preservation and protection of the faith, life and health, harm reduction programme is allowable and in fact provide an applied solution to the problem that could result in far greater damage to the society at large if left unaddressed. ${ }^{13}$ As He says in the Quran alBaqarah' 2:173 "But whoever is forced [by necessity], neither desiring [it] nor transgressing [its limit], there is no sin upon him. Indeed, Allah is Forgiving and Merciful". ${ }^{4}$

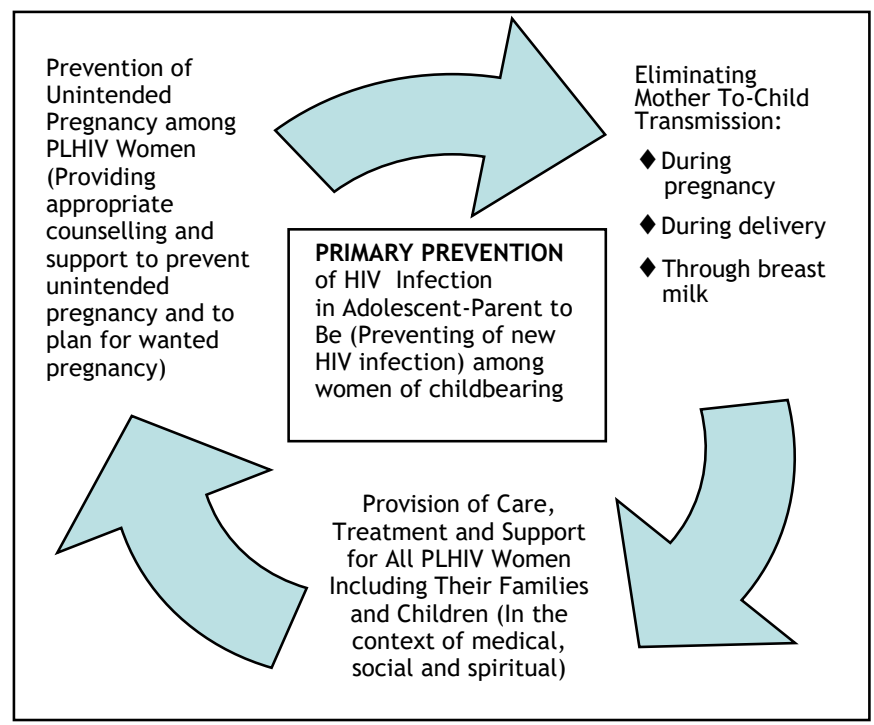

Figure-2: Integrated Strategies to Eliminate Mother-toChild Transmission (EMTCT)

Though the nation has provided PLHIV and their families undivided provision of care, treatment and supports; many PLHIV still fear stigmatization and discrimination which may lead to compromise of care. ${ }^{1}$ Emotional reactions which present as psychological distress through anger, fear, depression and denial worsened over time as the PLHIV faces family break-up, financial debility and loss of spouse. PLHIVs are more likely to develop mental distress in comparison with other chronic diseases. Effective counselling has a positive effect on patients coping with the disease and psychological distress. Counselling emphasizes on coping strategies which are essential for PLHIV. The involvement of religious leaders in these counselling sessions should be seriously considered. A study has shown when given proper training, religious leaders can become strong allies in HIV/AIDS prevention and control programme focused on awareness creation, constructive behavioral change, and the elimination of stigma and discrimination against PLHIV. ${ }^{14}$ Thus, cultivating spiritual and Islamic input during medical counselling could definitely give better outcome in curbing the disease. 


\section{ISLAMIC PERSPECTIVE}

Religious Approaches As A Prevention Strategy For HIV Transmission

Malaysia is a country comprised of multi-cultural and multi-religious population with Muslim being predominant. Religious approach particularly Islamic approach for HIV prevention could be one of the key strategies in preventing HIV transmission. Studies have found that Muslims who adhere more to Islamic teaching such as fasting, praying and forbidding prohibited act have lower risk to get HIV infection. ${ }^{15}$ Another study found that circumcision, a compulsory act practices by all Muslim males have the potential to reduce HIV transmission from infected female to uninfected male partner. ${ }^{16}$ These findings support the Islamic approach as a prevention strategy to reduce HIV transmission. Since the current shift of HIV transmissions from intravenous drug user to sexual related activities, these Islamic practices should be the focus of any approach planned.

Preserving a Safe and Healthy Sexual Life as Part of Prevention from HIV Infection

The Islamic teachings on the prevention and treatment of HIV/AIDS cover various aspects. These include the Islamic teachings in which men and women are obligated to guide and preserve sexual life (al-zawaj wa almuhafazah 'ala al-usrah). In this aspect, Islam presents integrated teachings that are set to guide and assist men and women to enjoy healthy and preserved marital life as mention in the Holy Quran chapter 2 verses 187 and chapter 30 verses $21 .^{4}$

These integrated teachings address various aspects of healthy social relations including encouraging marriage, preservation of sexual health and fulfilling dignified sexual desires by encouraging fidelity. Fidelity approach has been suggested to reduce HIV transmission. ${ }^{17}$ Promoting fidelity have been found to be effective in reducing the HIV transmission especially in a community with high prevalence of "religious people". ${ }^{18}$ This finding is definitely relevant in our country.

One of the basic Islamic teachings on social life is the promotion of marriage (al-zawaj); a legal union between man and woman by means of mutually agreed contract, and formally approved by relevant parts and authorities. As mentioned in chapter 24, verse $32 .{ }^{4}$ single men and women are invited to get married, whereby the Qur'an mentions that as long as unmarried individuals are physically and psychologically fit, financial challenges should not be an obstacle in preventing them to get married. Scientifically, studies have shown that being married reduced the risk for a man to have sex with other man. ${ }^{19}$ Marriage also reduced the behavior of unprotected anal sex among heterosexual intravenous drug users ${ }^{20}$ and another study found that being married will reduce the risk of having sex with multiple sexual partners. ${ }^{21}$ Additionally, a study also found that Muslim women perceived marriage as a way to protect them from abuse and oppression. ${ }^{22}$ Unlike other religious traditions, in which celibacy is promoted, Islam instead encourages marriage, which according to Islam is an effective way of guiding and appreciating sexual desires. Moreover, another study has found that promoting abstinence was ineffective in reducing HIV risk behaviors including sexual related activities. ${ }^{23}$

It is interesting to note that, in verse 32 , chapter 17 of the Qur'an states that Islam aims for regulated sexual intimacy with the prohibition of adultery and

Table 1: Regional \& Malaysia HIV Statistics-2017

\begin{tabular}{|c|c|c|c|c|c|}
\hline & $\begin{array}{l}\text { Prevalence Of } \\
\text { People Living With } \\
\text { Hiv (Plhiv) (\%) }\end{array}$ & $\begin{array}{l}\text { Prevalence Of } \\
\text { Women \& Girls } \\
\text { With Hiv (\%) }\end{array}$ & $\begin{array}{l}\text { New Hiv Infection } \\
\text { (\%) }\end{array}$ & $\begin{array}{l}\text { New Hiv } \\
\text { Infection In } \\
\text { Children 0-14 } \\
\text { Years Old (\%) }\end{array}$ & $\begin{array}{l}\text { Accessing } \\
\text { Anti-Retroviral } \\
\text { Therapy \% }\end{array}$ \\
\hline $\begin{array}{l}\text { Asia and } \\
\text { The } \\
\text { Pacific }\end{array}$ & $\begin{array}{l}5.2 \text { Million } \\
\text { (14\% Of Total } \\
\text { Number Of Plhiv } \\
\text { Globally) }\end{array}$ & & $\begin{array}{l}280,000 \\
(15 \% \text { Of Total New } \\
\text { Infection Globally) }\end{array}$ & $\begin{array}{l}10,000 \\
\text { (5.6\% Of Total } \\
\text { New Infection In } \\
\text { Children Globally) }\end{array}$ & $\begin{array}{l}2.7 \text { Million } \\
\text { (53\% Of Total } \\
\text { Plhiv In Asia And } \\
\text { The Pacific) }\end{array}$ \\
\hline Malaysia & $\begin{array}{l}72,399 \\
\text { (1.4\% Of Total } \\
\text { Plhiv In Asia And } \\
\text { The Pacific) }\end{array}$ & $\begin{array}{l}13,035 \\
\text { (11\% Of Total } \\
\text { Report Hiv In } \\
\text { Malaysia) }\end{array}$ & $\begin{array}{l}3,347 \\
\text { (1.2\% Of Total } \\
\text { New Infection In } \\
\text { Asia And The } \\
\text { Pacific) }\end{array}$ & $\begin{array}{l}1,168 \\
(11.6 \% \text { Of Total } \\
\text { New Hiv Infection } \\
\text { In Children In Asia } \\
\text { And The Pacific) }\end{array}$ & $\begin{array}{l}39,018 \\
\text { (54\% Of Total } \\
\text { Plhiv In Malaysia) }\end{array}$ \\
\hline
\end{tabular}


fornication as illegal sex (zina/homosex) opens the door to evil roads (wasa'a sabilan) including physical diseases and social chaos. ${ }^{4}$ This implies that achieving sexual desires through the right way honors marital life and leads to falah (success) of having legitimate offspring as mentioned in chapter 23, verses 1-6. ${ }^{4}$ Based on these teachings, Muslim jurists like al-Sheikh Yusuf al-Qaradawi, holds that diseases like HIV and AIDS appear due to the deviation from the right path or from the conducts of the natural course of life ( الانحر اف عن فطرة الله، وعن شرع الله، الممارسة In his recent interview by Al-Jazeera News channel on the Muslim jurists' perspective on the nature of HIV/AIDS, as well as the ways of treating the patients, he quoted the Prophetic Hadith in which the Prophet (s.a.w.) said that when illegal sex becomes acceptable in the public domain of the community, then such community is tested with diseases such as plague, diarrhea and other tribulations that were not known by their early generations. This means that HIV/AIDS is a test and tribulation to those who committed transgression in their sexual relations. Hence, the person with this disease should be seen as someone who is tested by Almighty, Allah (s.w.t.), due to his or her deviations from the right path. For PLHIV whom are considered among those who are tested (ibtila) in life, the public and relevant authorities should extend a helping hand to them, in terms of healthcare services, counseling, and adequate education and awareness on how to care for themselves and prevent transmission to others.

\section{Antiretroviral Therapy and Harm Reduction Programme from Islamic Perspective}

Based on the principle that "God never inflicts a disease without providing a cure for it", Islam encourages everyone to seek medical treatment. This is so because, for "He who put diseases on earth, has also put its remedy there", hence patients are advised to seek medical and healing remedy. Islam encourages a variety of medical treatments that are set to reverse disease pathology, mitigate its effects or stop further progress of its effect. Islam also permits using natural plants and products, as well as manufactured chemicals and surgical operations which are designed to correct reformatory baths of the body or to remove diseased tissues or perhaps to replace damaged cells and organs of the body. In line with the Islamic teachings on seeking medical treatment for a given ailment, HIV/AIDS patients are required to strive for seeking available treatment. As mentioned earlier, despite Islam seeing HIV and AIDS as 'tests' from Allah, the religion is not opposed to $A R T^{24}$. In fact, it is part of the prevention efforts (from husband to wife and mother to child transmission) that is well within Islamic teaching. Thus, every effort and support by health and Islamic bodies as well as Muslim leaders in Malaysia is required to intensify this preventive strategy.

Harm reduction programme from Islamic perspective has been long discussed either in Malaysia or worldwide. The programme has received split opinion from religious body. Despite the fact that Malaysia has adopted the programme since 2006, it has brought its own challenges especially from Islamic perspective. Malaysia's main Islamic authority namely Jabatan Agama Kemajuan Islam Malaysia (JAKIM) has made its statement in 2005 (prior to the national implementation of this programme) regarding its stand towards this programme. ${ }^{25}$ For example, the used of condom is restricted only to married couple on the principle of 'dar' $u$ al-mafasid muqaddam ala al-masolih'. Meanwhile, JAKIM went against the use of condom among unmarried couple for the reason that it may lead to 'zina' which is prohibited in Islam. As mentioned in chapter 17, verse 32 and elsewhere in the Holy Qur'an ${ }^{4}$, Islam aims for regulated sexual intimacy with the prohibition of adultery and fornication. ${ }^{20}$ In this verse, the Almighty, Allah (s.w.t.), commands mankind, to avoid committing all forms of illegal sex, i.e., zina, be it in the form of adultery or fornication. As for needle exchange, JAKIM also went against it on the basis of 'sad al-zarai'k' (blocking the means). This principle refers to the means which are most likely to lead to evil and rarely leads to benefit with most Islamic scholars have invalidated such means. However, JAKIM did support methadone used as part of the harm reduction programme stating that it is permissible in Islamic teaching. While this debate continues, the harm reduction programme is actively happening in Malaysia and it has showed positive impact in terms of the reduction of reported HIV cases as previously mentioned.

\section{CONCLUSION}

The preservation of the dignity of mankind which protects from harm and destruction are central to the teachings of Islam. The Quran and the Prophetic traditions or the Sunnah are the central sources of references for the laws and principles that guide the 
Muslims' way of life and treatment and by which policies and guidelines for responses including that of contemporary social and health care can be derived. Primary prevention should start from early adolescent period by integrating medical and Islamic teaching in schools addressing various aspects of social relations and preservation of sexual health as well as in cultivating noble way of living. God never inflicts a disease without providing a treatment for it and the treatment itself can also be a way of prevention. PLHIV should be self-empowered to take the treatment early and continue lifelong follow-up in which the process of healing and remedy should be conducted with efficiency and embraced with psychological support. It is critical for religious leaders to be meningfully involved to support PLHIV and to aid those who have been deviated and are affected by this disease to come back to the true path of Islamic teaching and . with good quality of life.

It has been shown that religious leaders can play important roles in HIV/AIDS prevention in view of their influence and acceptance among their respective congregations. It is highly recommended for us to develop a culture and religious-specific training materials to empower both healthcare providers and religious leaders to work with each other in the prevention, care and support endeavors. Hence, it is crucial for health and religious authorities to sit together and discuss arising issues and differences from time to time on the latest evidence available without ignoring the principle of Islamic teachings.

\section{REFERENCES}

1. Country Progress Report on HIV/AIDS 2018 Malaysia, Sector HIV/STI/Hepatitis C, Disease Control Division, Ministry of Health Malaysia. Available at: www.moh.gov.my/resources/.../ Country_Progress_Report_On_HIV_AIDS_2018.pdf Accessed March 12, 2019

2. Snapshot of HIV \& AIDS in Malaysia 2017 Published by Malaysian AIDS Council \& Malaysian AIDS Foundation. Available at: www.mac.org.my/v3/snapshot-of-hiv-aids-inmalaysia-2017/. Accesed February 20, 2019

3. Global AIDS Response Progress Report 2016, Disease Control Division, Ministry of Health Malaysia Available at: http:// www.moh.gov.my/images/gallery/Report/
Malaysia\%20GARPR\% 202016_Final.pdf. Accessed November 10, 2019.

4. Abdullah, Y. A. (1994). The Holy Quran: Text and translation. Kuala Lumpur: Islamic Book Trust.

5. Malaysian Consensus Guidelines on Antiretroviral Therapy 2017, Ministry of Health Malaysia. Available at: https://www.researchgate.net/ publication/319101215 Accessed in March 10, 2019

6. Initiation of Antiretroviral Therapy in Early Asymptomatic HIV Infection; the INSIGHT START Study Group, N Engl J Med 2015; 373:795-807. DOI: 10.1056/NEJMoa1506816

7. A Trial of Early Antiretroviral and Isoniazid Preventive Therapy in Africa; TEMPRANO ANRS Study Group. N Engl J Med. Aug 27 2015; 373 (9):808-822. DOI: 10.1056/NEJMoa1507198

8. Clinical Practice Guideline: Management of HIV Infection in Pregnant Women. Kuala Lumpur: Ministry of Health, Malaysia; 2008. Available at: http://www.acadmed.org.my/view_file.cfm. Accessed November 30, 2018

9. Malaysia 2015-2016 Validation of Elimination of Mother-to-Child Transmission of HIV \& Syphilis, Disease Control Division, Ministry of Health Malaysia. Available at: www.moh.gov.my/.../ Malaysia_EMTCT_Report_Final_version_May_29_ (DDG).pdf. Accessed March 12, 2019.

10. Ahmad N, Awaluddin SM et al. Sexual Activity Among Malaysian School-Going Adolescents: What Are the Risk and Protective Factors? Asia Pacific Journal of Public Health 26(5) July 2014. DOI: $10.1177 / 1010539514544700$

11. The National Strategic Plan for Ending AIDS 2016 -2030, HIV/STI Section of Ministry of Health Malaysia (2015) https: / /aidsdatahub.org/ national-strategic-plan-ending-aids-2016-2030hivsti-section- Accessed March 12, 2019

12. Bin Shaikh Mohd Salleh S.M.S., Kamarulzaman A. (2016) Implementation of an Islamic Approach to Harm Reduction Among Illicit Drug Users in Malaysia (pp 269-274). In: Kamali M., Bakar O., Batchelor DF., Hashim R. (eds) Islamic Perspectives on Science and Technology. Springer, Singapore, 978-981-287-777-2

13. A.Kamarulzamana1S.M.Saifuddeenb1, Islam and Harm Reduction, International Journal of Drug Policy, Volume 21, Issue 2, March 2010, Pages 115-118. In: Tim Rhodes et all. (eds) Special issue: Commentaries on Harm Reduction: Looking Back, Looking Forwards, ISSN: 0955-3959 
Copyright @ 2019 Elsevier B.V. All rights reserved.

14. Surur, Feiruz, and Mirgissa Kaba. "The Role of Religious Leaders in HIV/AIDS Prevention, Control, and Patient Care and Support: A Pilot Project in Jimma Zone." Northeast African Studies, vol. 7, no. 2, 2000, pp. 59-79. JSTOR, www.jstor.org/stable/41931343. Accessed on March 252019

15. Kagimu M, Guwatudde D, Rwabukwali C, et al. Religiosity for HIV prevention in Uganda: a case study among Muslim youth in Wakiso district. African Health Sciences. 2012;12(3):282 - 290.

16. Weiss HA, Hankins CA, Dickson K. Male circumcision and risk of HIV infection in women:a systematic review and meta-analysis. Lancet Infect Dis. 2009;9:669-77.

17. Communicable disease centre. HIV/AIDS: prevention. 2016. Available at: http:// www.cdc.gov/hiv/basics/prevention.html. Accessed on Sept 18, 2016.

18. Kippax S. Effective HIV prevention: the indispensable role of social science. $J$ Int AIDS Soc. 2012;15(2):17357.

19. Gant Z, Gant L, Song R, Willis L, Johnson AS. A census tract-level examination of social determinants of health among black/African American men with diagnosed HIV infection, 2005-2009--17 US areas. PLoS One. 2014;9 (9):e107701.

20. Mirabi P, Vasel MY, Moazen B, Sehat M, Rezazadeh M, Ahmadi K. Unprotected anal Intercourse among Iranian Intra-Venous Drug Users. Front Public Health. 2013;1:34.

21. Stein JA, Nyamathi A, Ullman JB, et al. Impact of Marriage on HIV/AIDS Risk Behaviors Among Impoverished, At-Risk Couples: A Multilevel Latent Variable Approach. AIDS Behav. 2007;11:87.

22. Alghafli Z, Hatch T, Marks L. Religion and Relationships in Muslim Families: A Qualitative Examination of Devout Married Muslim Couples. Religions. 2014;5(3):814-833.

23. C.Lo N, Lowe A, Bendavid E. Abstinence Funding Was Not Associated With Reductions In HIV Risk Behavior In Sub-Saharan Africa. Health Affairs. 2016;35(5):856-63.

24. Balogun AS. Islamic perspectives on HIV/AIDS and antiretroviral treatment: the case of Nigeria. African Journal of AIDS Research. 2010;9(4):45966.
25. Sumber maklumat al-Ahkam al Fiqhiyyah. Jabatan Agama Kemajuan Islam Malaysia. Available at: http://e-smaf.islam.gov.my/e-smaf/index.php/ main/mainv1/pandangan_pakar/5. Accessed on $20^{\text {th }}$ March 2019. 